\title{
Influences of Unemployment Rates and S\&P 500 Movements on Eight Selected Individual US Casino Stock Performances
}

\author{
Matiur Rahman \\ McNeese State University $\bullet$ Lake Charles, LA \\ Muhammad Mustafa \\ South Carolina State University • Orangeburg, SC \\ Stephen Caples \\ McNeese State University $\bullet$ Lake Charles, LA
}

\section{ABSTRACT}

This paper studies the causal effects of changes in unemployment rates and U.S. S\&P 500 returns on changes in stock returns of selected eight U.S. casinos individually. Monthly data from January, 1982 through July, 2012 are employed. The time series data in percentage changes are found stationary. As a result, multivariate VAR in first-difference is implemented since the objective is to investigate the effects of changes in causal variables on changes in individual selected casino stock returns. The estimates depict weakly positive and somewhat mixed causal influences of changes in unemployment rates on changes in casino stock returns. In the case of the changes in S\&P 500, the results are uniformly positive and relatively strong. In other words, the latter unleash stronger influence than the former on changes in casino stock returns with mixed net short-run interactive feedback effects. ${ }^{1}$

\section{INTRODUCTION}

Casino stocks, in general, are considered sin stocks like tobacco and alcohol stocks. Socially responsible, ethical, and environment-friendly investors tend to avoid them in their portfolios. However, such investors seem to enjoy gaming, tobacco and alcohol regardless of economic conditions and political tensions (Berman, 2002; Ahrens, 2004; and Waxler, 2004). Sin stocks, as a whole, are defensive ( $\beta<$ 1) but casino gaming stocks seem to be more aggressive $(\beta>1){ }^{2}$ Thus, these stocks individually outperform the stock market during bad times because of limited risk sharing. Their excess returns, in general, are higher when the overall stock market is down than when the market is up. The casinos use more private debt than equity 
financing, and they have superior financial reporting quality than other stock issuing entities. In short, casino stocks add "sizzles" to securities portfolios of individuals.

The casino gaming is a multi-billion dollar industry in the USA. In 2010, total casino gaming revenue was flat at $\$ 57.5$ billion as compared to 2006 . This is expected to grow to $\$ 73.3$ billion in 2015 presenting a cumulative average growth rate of 5 percent during the forecast period of 2011-2015. Actual amounts of US casino gaming revenue for 2006-2010 and the forecast amounts thereof for 2011-2015 are shown in Appendix A-I. In conjunction with it, the trend is shown for the same sub-periods for global casino gaming revenue in Appendix A-II (www.casinoenterprisemanagement.com/january-2012/pwc).

To examine the time series properties of each variable in percentage change form, the DF-GLS test for unit root and the KPSS test for no-unit root are implemented. On the evidence of stationarity of each variable, the VAR model in first-difference is estimated for each selected casino stock returns for short-run causal flows and interactive feedback effects. Usually, VAR is recommended to be estimated in levels for stationary variables. However, first-differencing or overdifferencing of stationary variables for VAR's is also appropriate for robust estimates (Marcet, 2005).

The primary objective of this paper is to investigate the causal influences of changes in unemployment rates and those of the U.S. stock market (S\&P 500) returns on the changes in returns of eight selected U.S. casino stocks, individually. This paper is motivated to study whether the stock prices of the selected casinos are countercyclical. The casino stock prices are considered individually to gain some micro-level insight. The remainder of this paper proceeds in sequence as follows: brief review of related literature, empirical methodology, results, and conclusions.

\section{BRIEF REVIEW OF RELATED LITERATURE}

Sin stock returns over various phases of business cycle are likely to be less sensitive to business conditions than other stocks. During bad economic times, they also tend to outperform other stocks. Academic research by Hong and Kacperczyk (2009) documented that sin stocks are underpriced with positive alphas ${ }^{3}$, consistent with the portfolio theory. They study the performance of sin stocks in relation to the US stock market over the period of 1965-2003. Based on an unconditional four-factor model which controls for market premium, size, book-to-market and past returns, they argue that sin stocks outperform the stock market because they are not 
held by institutions subject to social norms. While gauging the relative importance of litigation risk versus this neglected-stock effect, the authors find that litigation risk cannot explain the abnormal returns on sin stocks. This neglect-effect implies risk-sharing with higher expected returns. Further, Hong and Kacperczyk (2009) study the financing decisions of sin companies and find that they use more private debt financing than equity financing. Kim and Mohan (2006) examine whether this neglected effect is attributable to differential information risk for these firms. They show that sin firms' financial reporting quality is superior to a control group of firms due to greater regulatory scrutiny.

Hong and Kacperczyk (2009) form a sin-stock portfolio and compare its average return to an industry-comparable portfolio. The performance of sin stocks over the business cycle has not been examined from an industry point of view, except for gaming stocks. Goodall (1994) studies gaming stock returns over a 20 -year horizon, and find that they tend to be more volatile than the market as a whole. In addition, some special events can cause the gaming stocks to move in a direction opposite to the general stock market. The above results are driven by the relatively small capitalization of these stocks. In addition, this study shows that gaming stocks are more sensitive to stock market declines. Chen and Feng-Shun (2001) study U.S. gaming stock returns over up and down markets, using CAPM regression with time-varying alphas and betas, in a GARCH estimation framework. They show that investors earned negative excess return at an above-market-average systematic risk for holding stocks of gaming companies over 1993-1997. After changes in market conditions were considered, however, the investors in gaming stocks gained a relatively normal return at an abnormal level of risk as compared to the market average systematic risk. But the excess return on sin stocks was higher during down markets than during up markets. They also investigate the effects of legislation events on gaming stock returns, and find that small casino operators are more reactive to deregulation/regulation actions in comparison with large casino gaming firms.

Fabozzi, et al., (2008) examine the issue of how social values affect economic values. Based on a small subset of the stock universe that has been generally associated with sin-seeking activities, such as alcohol consumption, adult services, gaming, tobacco, weapons, and genetic engineering, the authors find that a sin-stock portfolio produced an annual return of $19 \%$ over the study period, unambiguously outperforming common benchmarks in terms of both magnitude and frequency. Several likely reasons for the positive excess returns in sin stocks are identified. The 
authors argue that trustees or fiduciaries who develop institutional investment policy statements should fully understand the economic consequences of screening out stocks of companies that produce a product inconsistent with their value systems. In general, stock returns and unemployment rate reveal causality that runs from stock market to unemployment (Geske and Roll, 1983). Causality between unemployment and Small Cap Returns has also been investigated in Moscarini and Postel-Vinay (2010). They find a distinctly similar cyclical pattern in both large cap and small cap stock performances. Both papers thus underscore the importance of the inclusion of unemployment in this study relating to stock market returns. More recently, Farsio and Fazel (2013) investigate the relationship between unemployment rate and stock prices in USA, China and Japan challenging the assertion that unemployment rate is a strong predictor of stock prices (Little, 2010 and Wojdylo, 2009). They conclude analyzing the data over the 1970-2011 period that it would be a mistake to rely on unemployment rate data to make investment decision in stock market.

\section{EMPIRICAL METHODOLOGY}

In general functional form, the estimating model is as follows:

$$
Y_{t}=f\left(\begin{array}{cc}
\mathrm{U}_{\mathrm{t}}, \mathrm{X}_{\mathrm{t}} \\
(+)(+)
\end{array}\right)
$$

where,

$\mathrm{Y}_{\mathrm{t}}=$ individual casino's monthly stock return,

$\mathrm{U}_{\mathrm{t}}=$ monthly U.S. unemployment rate, and

$\mathrm{X}_{\mathrm{t}}=$ monthly return on $\mathrm{S} \& \mathrm{P} 500$.

The expected sign of causal flow of each explanatory variable is indicated underneath. The time series properties of each variable are investigated by implementing the modified Dickey-Fuller test (DF-GLS) following Elliot et al. (1996), and $\mathrm{Ng}$ and Perron (2001). The KPSS test as its counterpart is also applied following Kwaitkowski et al., (1992). The DF-GLS test is about data non-stationarity for the null hypothesis of unit root in each time series variable while the KPSS test is about the null hypothesis of no-unit root in each time series variable. Testing for nonstationarity of each time series variable is essential to ascertain the application of a correct estimating technique since the application of OLS on nonstationary variables leads to the problem of spurious correlation inducing bias and inefficiency in the estimated parameters (Granger and Newbold, 1974). 
On the evidence of stationarity in each time series variable, the following VAR model in first-difference is estimated in line with (Granger, 1998) for individual stock return:

$$
\Delta Y_{t}=\alpha+\sum_{\mathrm{n}=1}^{\mathrm{n}} \pi_{2} \pi_{2} \Delta Y_{t-i}+\sum_{i=1}^{\mathrm{K}} \theta_{i} \Delta U_{t-i}+\sum_{i=1}^{\mathrm{m}} \beta_{i} \Delta X_{t-i}+e_{t}
$$

Here, $\mathrm{e}=$ error term, $\mathrm{t}=$ time subscript, $\mathrm{i}=$ represents optimum number of lags and $\Delta=$ first-difference operator. The estimated coefficients of the lagged explanatory variables and their statistical significance display short-term causal flows to the dependent variable with net interactive feedback effects. The optimum lag-lengths are determined by the Final Prediction Error (FPE) criterion following Akaike (1969) to overcome the problems of over-parameterization and under-parameterization that may also induce bias and inefficiency in the estimated parameters. Time Series data on Macroeconomic variables can be nonstationary in levels with the first order of integration, but not cointegrated. In this case, a multivariate VAR with first-differencing of variables in a single equation captures short-run dynamic causal effects with interactive feedback (Bahmani and Payesteh, 1993).

The VAR-family has several variants in levels or in first-difference of variables included in the estimating model(s). A multivariate VAR is natural extension of the standard univariate VAR. A shortcoming of the standard framework for Granger causality is that it only allows for examination of dynamic interactions between single (univariate) variables within a system, perhaps conditioned on other variables. However, interactions do not necessarily take place between single variables but may occur among groups or "ensembles" of variables. This study thus establishes a framework for Granger causality in the context of causal interactions among three variables (Barrett et al., 2010). Moreover, Multivariate VAR often provides superior forecasts to those from univariate time series models requiring less a priori information (Gujarati, 1995). The time profile causal impacts of unexpected shocks or innovations to specific variables on the variables in the model are usually summarized with impulse response functions within the VAR-frameworks for business-cycle analyses (Greene, 2007 and Watson, 1994). A historical variance decomposition of variables is also useful to assessing the driving forces of cyclical fluctuations in VAR-form (Gali, 1999, and King et al., 1991). Transfer Function is an alternative to VAR that does not require either impulse response or variance decomposition analysis. This is used in intervention analysis, but it may be of a little practical value due to unduly high over parameterization (Newbold and Bos, 1990).

Monthly data on all variables are collected from January, 1982 through July, 2012. The data source includes Ameristan Casinos Inc (ASCA: NASDAQ GS). 
Brief descriptions of the eight selected U.S. casinos are provided in Appendix B. In addition to data availability, they have been selected for broader geographic network, market capitalization and significant sales volumes.

\section{RESULTS}

The simple correlation coefficients of 8 selected U.S. casino stock returns and causal variables $\left(u_{t}\right.$ and $\left.x_{t}\right)$ are reported as follows:

As observed in Table 1, the pair-wise simple correlation coefficients of casino stock returns are positive. The magnitudes are from moderate to high. However, they may change across sample periods due to changes in macro-economic conditions. Furthermore, correlation does not imply causality. As observed above, the simple correlation coefficient between unemployment rates and S\&P 500 returns is positive and very low at 0.1761 suggesting very marginal multi-colinearity for linear dependence of explanatory variables. Both unemployment rates and S\&P 500 returns are exogenous as they are generated outside the equation of interest (Engle, Hendry and Richard, 1983).

Next, the time series properties of each variable are examined by implementing the DF-GLS and the KPSS tests. The results are reported as follows: 
Table 1

Correlation Matrix

Sample: (January, 1982 - July, 2012)

\begin{tabular}{|c|c|c|c|c|c|c|c|c|c|c|c|}
\hline & $\begin{array}{l}\overparen{\infty} \\
\sum^{\prime} \\
z_{\alpha}\end{array}$ & & & & & & & & & & \& \\
\hline 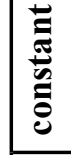 & 选 & & & & & & & & & $\begin{array}{l}8 \\
8 \\
\stackrel{8}{+}\end{array}$ & $\begin{array}{l}\mathscr{1} \\
0 \\
\varnothing ి \\
0 \\
0\end{array}$ \\
\hline ত্ডি & $\frac{N}{x}$ & & & & & & & & $\underset{8}{8}$ & \begin{tabular}{l|}
$\infty$ \\
\\
0 \\
0 \\
0
\end{tabular} & $\begin{array}{l}\tilde{N} \\
\hat{1} \\
0 \\
0 \\
0\end{array}$ \\
\hline$z^{\bar{y}}$ & $\begin{array}{l}\frac{10}{z} \\
z \\
\Sigma\end{array}$ & & & & & & & $\begin{array}{l}8 \\
8 \\
\\
\leftarrow\end{array}$ & $\begin{array}{l}8 \\
8 \\
0 \\
0 \\
0 \\
\end{array}$ & $\begin{array}{l}\mathscr{L} \\
\mathscr{D} \\
\infty \\
0 \\
0 \\
0\end{array}$ & 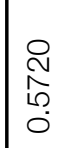 \\
\hline$\xi^{\Sigma}$ & $\frac{Z_{1}}{2}$ & & & & & & $\begin{array}{l}8 \\
8 \\
\end{array}$ & $\mid$\begin{tabular}{l}
\multirow{f}{N}{} \\
$\tilde{L}$ \\
0 \\
0 \\
0
\end{tabular} & \begin{tabular}{|l|}
$\overline{0}$ \\
2 \\
0 \\
0 \\
\end{tabular} & $\begin{array}{l}\mathcal{N}_{0} \\
\infty \\
0 \\
0 \\
0\end{array}$ & 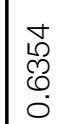 \\
\hline$\overbrace{}^{i}$ & $\begin{array}{l}\bar{N} \\
\sum \\
\sum \\
\sum \\
\sum\end{array}$ & & & & & $\begin{array}{l}8 \\
8 \\
8\end{array}$ & 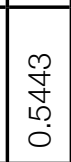 & \begin{tabular}{|l}
0 \\
$\tilde{N}$ \\
0 \\
0 \\
0 \\
0
\end{tabular} & $\mid \begin{array}{l}\hat{D} \\
\stackrel{\circ}{\rho} \\
0 \\
0 \\
0\end{array}$ & $\begin{array}{l}1 \\
\infty \\
\infty \\
0 \\
0 \\
0\end{array}$ & $\begin{array}{l}\tau \\
\hat{N} \\
0 \\
0\end{array}$ \\
\hline $2^{\tilde{\Xi}}$ & & & & & $\underset{+}{8}$ & \begin{tabular}{|l}
$\infty$ \\
0 \\
$\stackrel{2}{R}$ \\
0 \\
0
\end{tabular} & $\mid \begin{array}{c}\tau \\
\tilde{\sigma} \\
\tilde{\sigma} \\
0 \\
0\end{array}$ & $\begin{array}{l}\tilde{N} \\
m \\
\overline{0} \\
0\end{array}$ & $\begin{array}{l}\stackrel{v}{\sim} \\
\widetilde{N} \\
0 \\
0 \\
0\end{array}$ & 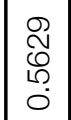 & $\begin{array}{l}\text { 足 } \\
0 \\
0 \\
0 \\
0 \\
0\end{array}$ \\
\hline$R^{\tilde{g}}$ & $\begin{array}{l}\bar{\sum} \\
D \\
\geq\end{array}$ & & & $\begin{array}{l}8 \\
8 \\
\stackrel{8}{-}\end{array}$ & $\begin{array}{c}\infty \\
\infty \\
N \\
\infty \\
0 \\
0\end{array}$ & \begin{tabular}{|l}
$\tilde{N}$ \\
$\tilde{O}$ \\
0 \\
0 \\
0 \\
0
\end{tabular} & $\begin{array}{l}\stackrel{\infty}{\mathrm{N}} \\
\stackrel{5}{0} \\
0\end{array}$ & \begin{tabular}{|l|l|}
$\infty$ \\
0 \\
0 \\
0 \\
0 \\
0
\end{tabular} & \begin{tabular}{|l|}
8 \\
8 \\
0 \\
0 \\
0 \\
0
\end{tabular} & 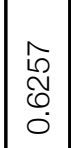 & \begin{tabular}{|l}
$\infty$ \\
$\infty$ \\
$\varnothing$ \\
0 \\
0
\end{tabular} \\
\hline $2^{t}$ & $\begin{array}{l}\infty \\
0 \\
\infty \\
\infty \\
\infty\end{array}$ & & $\begin{array}{l}8 \\
8 \\
\\
-\end{array}$ & \begin{tabular}{|l|}
\multirow{T}{N}{} \\
$\hat{\sigma}$ \\
$\dot{0}$ \\
\end{tabular} & \begin{tabular}{l}
$\bar{\rho}$ \\
\multirow{\rho}{*}{} \\
$\dot{0}$
\end{tabular} & \begin{tabular}{|l}
0 \\
0 \\
$i n$ \\
0 \\
0 \\
0
\end{tabular} & $\begin{array}{l}\circ \\
0 \\
0 \\
0 \\
0 \\
0\end{array}$ & $\begin{array}{l}10 \\
1 \\
0 \\
0 \\
0 \\
0\end{array}$ & $\begin{array}{l}\tilde{N} \\
\text { లె } \\
0 \\
0\end{array}$ & 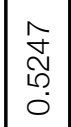 & $\begin{array}{l}0 \\
10 \\
0 \\
0 \\
0 \\
0\end{array}$ \\
\hline ن & 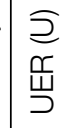 & $\begin{array}{l}8 \\
8 \\
\end{array}$ & $\begin{array}{l}\bar{c} \\
\stackrel{1}{\sigma} \\
\vdots \\
0\end{array}$ & $\begin{array}{l}8 \\
\stackrel{8}{\circ} \\
\div \\
\circ\end{array}$ & $\begin{array}{l}\stackrel{N}{N} \\
\stackrel{+}{\sigma}\end{array}$ & $\begin{array}{l}m \\
\text { m } \\
\vdots \\
\vdots \\
0\end{array}$ & $\begin{array}{l}\hat{O} \\
\qquad 0 \\
0 \\
\circ\end{array}$ & \begin{tabular}{|l} 
fo \\
$\infty$ \\
0 \\
0 \\
0
\end{tabular} & 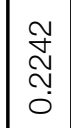 & $\begin{array}{l}2 \\
0 \\
\infty \\
0 \\
0 \\
0\end{array}$ & 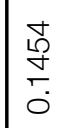 \\
\hline 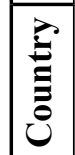 & & 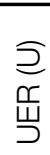 & $\begin{array}{l}8 \\
8 \\
\infty \\
\infty \\
\infty \\
\infty\end{array}$ & $\begin{array}{l}\tilde{E} \\
\infty \\
D\end{array}$ & $\frac{1}{3}$ & $\begin{array}{l}\tilde{N} \\
\sum \\
\sum \\
\sum \\
\sum\end{array}$ & $\frac{z}{2}$ & 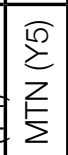 & एu & 交 & $\mid \begin{array}{l}\infty \\
\Sigma \\
y \\
z \\
0\end{array}$ \\
\hline
\end{tabular}


Table 2

\section{Unit Root Tests}

\begin{tabular}{|c|c|c|}
\hline & \multicolumn{2}{|c|}{ LEVEL } \\
\hline SERIES & DF-GLS & KPSS \\
\hline UER $(U)$ & $-11.61586^{\star}$ & $0.30350^{\star *}$ \\
\hline S\&P $500(X)$ & $-14.6874^{*}$ & $0.06925^{\star \star}$ \\
\hline $\operatorname{LVS}\left(Y_{p}\right)$ & $-3.8239^{\star}$ & $0.09700^{\star \star}$ \\
\hline WYNN $\left(Y_{2}\right)$ & $-9.6807^{\star}$ & $0.06920^{\star \star}$ \\
\hline $\operatorname{MGM}\left(Y_{3}\right)$ & $-16.8845^{\star}$ & $0.02330^{\star \star}$ \\
\hline $\operatorname{PENN}\left(Y_{4}\right)$ & $-14.4548^{*}$ & $0.04381^{\star *}$ \\
\hline $\operatorname{MTN}\left(Y_{5}\right)$ & $-11.5055^{\star}$ & $0.051941^{\star *}$ \\
\hline $\operatorname{CAKE}\left(Y_{\sigma}\right)$ & $-12.0066^{\star}$ & $0.06118^{\star *}$ \\
\hline $\operatorname{ASCA}\left(Y_{\nu}\right)$ & $-13.6191^{*}$ & $0.08659^{\star *}$ \\
\hline $\operatorname{PNK}\left(Y_{8}\right)$ & $-19.5814^{*}$ & $0.03380^{\star *}$ \\
\hline \multicolumn{3}{|c|}{$\begin{array}{l}{ }^{*} \text { Significant at } 1 \% \text { level. }{ }^{* *} \text { Less than the critical values of } 0.739,0.463 \text {, } \\
\text { and } 0.347 \text { respectively at } 1 \%, 5 \% \text {, and } 10 \% \text { levels of significance failing } \\
\text { to reject the null hypothesis of no unit root. }\end{array}$} \\
\hline
\end{tabular}

Table 2 reveals that the null hypothesis of unit root for DF-GLS test is clearly rejected at $1 \%$ level of significance (as indicated by *). For KPSS test results, the null hypothesis of no unit root cannot be rejected at 1, 5 and 10 percent levels of significance (as indicated by $* *$ ). Thus, there are clear evidences of stationarity in all the variables, based on the aforementioned tests. To note, non-stochastic explanatory variables are strongly exogenous for all the parameters (Greene, 2007).

The impulse response analyses due to a given external shock by one standard deviation in S\&P 500 returns and unemployment rates unleash short-lived effects on individual casino stock returns (Appendix - C). The historical variance decompositions of variables depict modest and decaying variability, as evidenced in Appendix - D. 
Finally, the VAR model, as outlined in equation (2), is estimated for changes in each individual selected casino stock returns. The results are reported in Table 3. A close inspection shows that changes in each casino stock returns are influenced positively and more pronouncedly by changes in the overall US stock market returns than by those in US unemployment rates with two exceptions. They are revealed in coefficients and their associated t-values for individual casino stock returns. The respective sums of the contemporaneous and lagged coefficients of the changes in S\&P 500 returns and unemployment rates indicate mixed net short-run interactive feedback effects.

\section{CONCLUSIONS}

The selected eight U.S. individual casino stock returns are influenced positively by movements in the US stock market (S\&P 500) returns. Six stocks are positively and weakly influenced by the changes in unemployment rates with one-period lag, while two stocks are negatively and weakly influenced. In short, the evidences are somewhat mixed in this regard. Comparatively, the U.S. stock market returns unleash positive influences on the selected eight casino stock returns with greater strength. The influences of changes in unemployment rates on these stock returns are weak and inconclusive to some extent. So, changes in unemployment rates appear not to be a good predictor of Casino stock returns. In closing, the findings of this paper to draw any general and firm conclusion on the countercyclical behavior of casino stock returns should, therefore, be weighed with due caution. 
Table 3

Vector Autoregression Estimates*

\begin{tabular}{|c|c|c|c|c|c|c|c|c|c|c|c|c|c|c|c|c|c|c|c|}
\hline \multirow{8}{*}{ 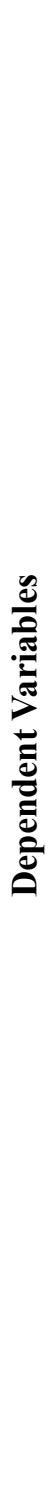 } & $\frac{1}{Z}$ & $\begin{array}{l}\hat{\Omega} \\
\text { Na } \\
\text { م) } \\
0 \\
0 \\
0\end{array}$ & 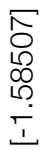 & 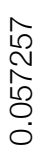 & 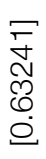 & $\begin{array}{l}0 \\
0 \\
\\
0 \\
0 \\
0 \\
0 \\
0\end{array}$ & 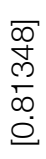 & $\begin{array}{l}\bar{\sigma} \\
\overline{8} \\
\stackrel{0}{N} \\
0\end{array}$ & $\begin{array}{l}\text { J } \\
\text { Ð } \\
\stackrel{5}{\sigma} \\
\dot{0}\end{array}$ & 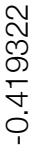 & $\begin{array}{l}\widetilde{V} \\
\infty \\
\llcorner \\
\llcorner \\
\infty \\
\ulcorner \\
\square\end{array}$ & 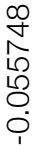 & 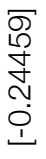 & & & & & & \\
\hline & $\underset{\Downarrow}{\ll}$ & $\begin{array}{l}\hat{\approx} \\
\text { Nิ } \\
\hat{0} \\
0 \\
0 \\
0\end{array}$ & 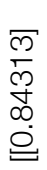 & $\begin{array}{l}\Omega \\
\infty \\
0 \\
0 \\
0 \\
0 \\
0 \\
1\end{array}$ & $\begin{array}{l}1 \\
\infty \\
\infty \\
0 \\
0 \\
0 \\
0 \\
1\end{array}$ & $\begin{array}{l}\infty \\
0 \\
m \\
\\
0 \\
0 \\
1\end{array}$ & 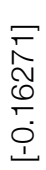 & 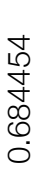 & 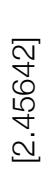 & 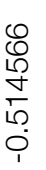 & 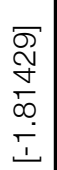 & 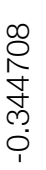 & 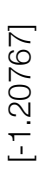 & & & & & & \\
\hline & $\frac{1}{2}$ & $\begin{array}{l}\frac{N}{\sigma} \\
\frac{\sigma}{8} \\
\frac{0}{0}\end{array}$ & 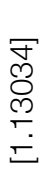 & $\begin{array}{l}m \\
\frac{m}{\sigma} \\
0 \\
8 \\
0 \\
0 \\
1\end{array}$ & 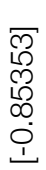 & 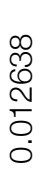 & \begin{tabular}{l}
$\bar{\Gamma}$ \\
$\stackrel{5}{N}$ \\
\multirow{N}{0}{} \\
$\stackrel{0}{0}$
\end{tabular} & 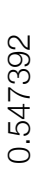 & 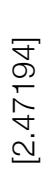 & $\begin{array}{l}\text { の } \\
\infty \\
0 \\
\infty \\
\infty \\
\\
\\
\end{array}$ & 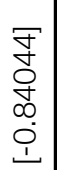 & 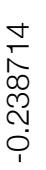 & $\begin{array}{l}\bar{\sigma} \\
0 \\
0 \\
0 \\
\\
\end{array}$ & & & & & & \\
\hline & Z & 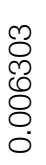 & 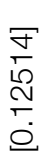 & $\begin{array}{l}\text { No } \\
\text { Nิ } \\
\stackrel{8}{8} \\
0 \\
0\end{array}$ & $\begin{array}{l}\bar{\Gamma} \\
\stackrel{0}{\rho} \\
\varnothing \\
0 \\
0\end{array}$ & & & 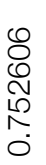 & $\begin{array}{l}\square \\
\text { ח } \\
\infty \\
\infty \\
\infty \\
\text { ल. }\end{array}$ & 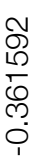 & $\begin{array}{l}\square \\
\infty \\
0 \\
0 \\
\infty \\
\Gamma \\
\end{array}$ & & & & & & & & \\
\hline & 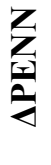 & 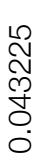 & $\begin{array}{l}\text { N } \\
\sim \\
\text { Nิ } \\
0 \\
0\end{array}$ & \begin{tabular}{l}
\multirow{2}{0}{} \\
\multirow{8}{*}{} \\
\multirow{0}{*}{} \\
0 \\
0
\end{tabular} & 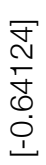 & & & 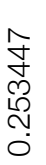 & $\begin{array}{l}\hat{N} \\
\hat{N} \\
\text { ô } \\
0\end{array}$ & 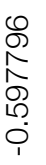 & 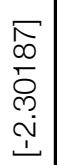 & & & & & & & & \\
\hline & $\sum_{\circlearrowright}$ & 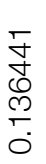 & 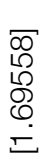 & 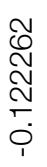 & 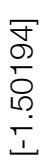 & & & 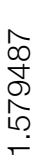 & $\begin{array}{l}\mathbf{0} \\
\mathbb{0} \\
0 \\
0 \\
0 \\
1\end{array}$ & 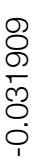 & 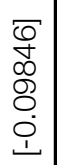 & & & & & & & & \\
\hline & $\sum_{z}^{Z}$ & 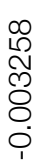 & 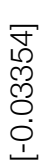 & $\begin{array}{l}\frac{1}{\frac{1}{m}} \\
\frac{5}{0} \\
0\end{array}$ & $\begin{array}{l}\infty \\
\infty \\
\stackrel{0}{ } \\
\text { m } \\
\square \\
\dot{0}\end{array}$ & & & 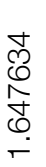 & 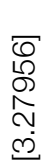 & 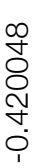 & 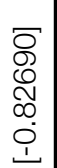 & & & & & & & & \\
\hline & $\frac{\infty}{2}$ & $\begin{array}{l}\frac{1}{10} \\
\frac{1}{0} \\
\frac{0}{0} \\
0\end{array}$ & 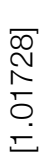 & 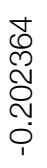 & $\begin{array}{l}\bar{\sigma} \\
\infty \\
0 \\
\infty \\
\infty \\
0 \\
\end{array}$ & \begin{tabular}{l}
5 \\
O \\
\multirow{4}{*}{} \\
$\stackrel{0}{0}$ \\
0
\end{tabular} & 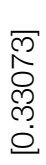 & $\begin{array}{l}\mathscr{8} \\
8 \\
0 \\
\mathscr{0} \\
\infty \\
-\end{array}$ & 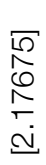 & 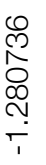 & 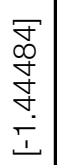 & 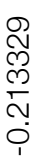 & 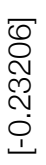 & 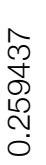 & 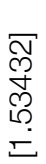 & 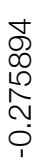 & 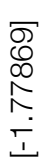 & 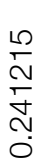 & 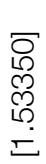 \\
\hline 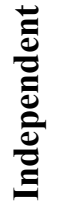 & $\frac{\frac{a}{0}}{\frac{a}{\pi}}$ & & 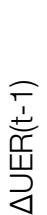 & & 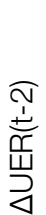 & & 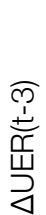 & & 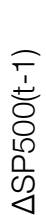 & & 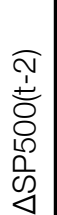 & & 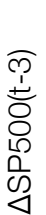 & & 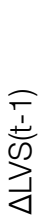 & & 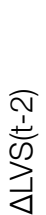 & & 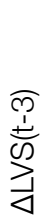 \\
\hline
\end{tabular}




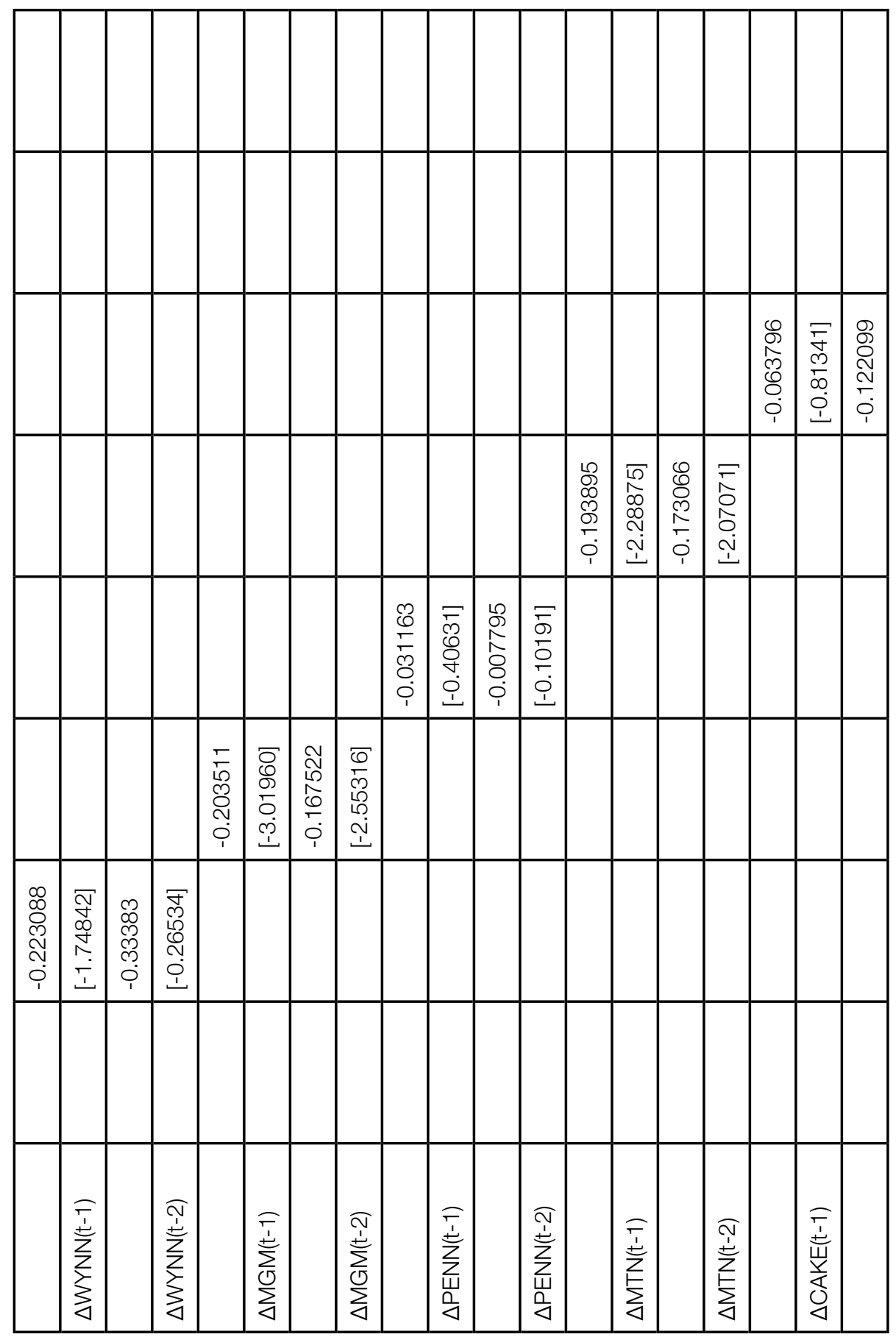




\begin{tabular}{|c|c|c|c|c|c|c|c|c|c|c|c|c|c|c|c|c|}
\hline & & & & & & & & & 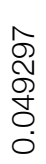 & $\begin{array}{l}\text { D } \\
\text { } \\
\text { N } \\
\text {. }\end{array}$ & \begin{tabular}{l}
\multirow{2}{0}{} \\
$\infty$ \\
$\infty$ \\
$\infty$ \\
0 \\
0 \\
0
\end{tabular} & $\begin{array}{l}\text { న } \\
\hat{\infty} \\
\infty \\
\infty \\
0\end{array}$ & \begin{tabular}{l}
$\infty$ \\
$\stackrel{\infty}{\sim}$ \\
\multirow{J}{*}{} \\
0 \\
0 \\
1
\end{tabular} & $\begin{array}{l}\overline{0} \\
\hat{n} \\
0 \\
0 \\
0 \\
1\end{array}$ & $\begin{array}{l}\infty \\
1 \\
0 \\
0 \\
1 \\
0 \\
0 \\
0 \\
\end{array}$ & 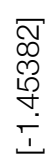 \\
\hline & & & 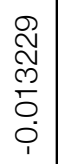 & 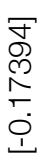 & 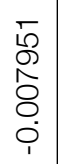 & 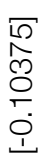 & \begin{tabular}{l}
\multirow{2}{D}{} \\
N \\
0 \\
0 \\
0
\end{tabular} & 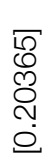 & & & & & & & 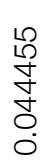 & 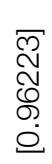 \\
\hline 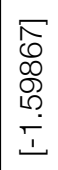 & $\begin{array}{l}\infty \\
\text { ల } \\
0 \\
0 \\
0 \\
0 \\
\dot{1}\end{array}$ & 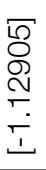 & & & & & & & & & & & & & 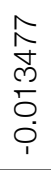 & 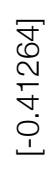 \\
\hline & & & & & & & & & & & & & & & 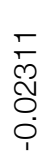 & $\begin{array}{l}\text { D } \\
\text { N } \\
\sim \\
\infty \\
0 \\
1\end{array}$ \\
\hline & & & & & & & & & & & & & & & \begin{tabular}{l}
0 \\
\multirow{J}{*}{} \\
$\stackrel{\text { J }}{0}$ \\
$\dot{0}$
\end{tabular} & $\begin{array}{l}\frac{\nabla}{\sigma} \\
\stackrel{0}{0} \\
\vdots \\
亡\end{array}$ \\
\hline & & & & & & & & & & & & & & & 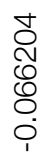 & 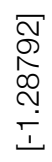 \\
\hline & & & & & & & & & & & & & & & $\begin{array}{l}\stackrel{9}{+} \\
\frac{1}{5} \\
\infty \\
\vdots \\
0 \\
1\end{array}$ & 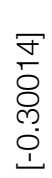 \\
\hline & & & & & & & & & & & & & & & $\begin{array}{l}\stackrel{\sim}{\sim} \\
0 \\
\infty \\
\infty \\
0 \\
0 \\
1\end{array}$ & $\begin{array}{l}\nwarrow \\
\bigcirc \\
\infty \\
\infty \\
\infty \\
0 \\
1 \\
\end{array}$ \\
\hline 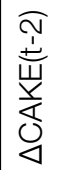 & & 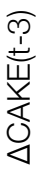 & & 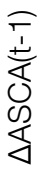 & & 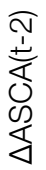 & & 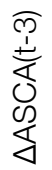 & & 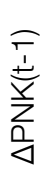 & & 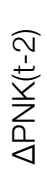 & & 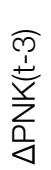 & & 0 \\
\hline
\end{tabular}




\section{REFERENCES}

Ahrens, D. (2004). Investing in Vice: The Recession- Proof Portfolio of Booze, Bets, Bombs, and Butts. NewYork, NY: St. Martin Press.

Akaike, H. (1969). Fitting autoregression for prediction. Annals of the Institute of Statistical Mathematics, 21, 243-247.

Bahmani, O.M. \& Payesteh, S. (1993). Budget deficits and the value of the dollar: An application of cointegration and error-correction modeling. Journal of Macroeconomics, 15, 661-677.

Barrett, A. B., Bamett, L., \& Seth, A. K. (2010). Multivariate granger causality and generalized variance. American Physical Society, 81(4), 041907.

Berman, D. (2002). Why sin is good: Tobacco, alcohol, and gaming stocks can add sizzle to your portfolio. Money Sense. November.

Chen, D.H., \& Feng-Shun, B. (2001). Effects of legislation events on U.S. gaming stock returns and market turnings. Tourism Management, 22, 539-549.

Elliot, G., Rothenberg, T.J., \& Stock, J.H. (1996). Efficient test for an autoregressive unit root. Econometrica, 64, 813-836.

Engle, R.F., Hendry, D.F., \& Richard, J.F. (1983). Exogeneity, Econometrica, 51, 277-304.

Fabozzi, F.J., Ma, K.C., \& Oliphant, B.J. (2008). Sin stock returns. Journal of Portfolio Management, 35, 82-94.

Gali, J. (1999). Technology, employment and the business cycle: Do technology shocks explain aggregate fluctuations? American Economic Review, 89, 249271.

Geske, R., \& Roll, R. (1983). The fiscal and monetary linkage between stock returns and inflation. Journal of Finance, 38, 1-33.

Gujarati, D. (1995). Basic econometrics, (3rd Ed.). New York, NY: McGraw-Hill.

Farsio, F., \& Fazel, S. (2013). The stock market/unemployment relationship in USA, China and Japan. International Journal of Economics and Finance, 5, 24-29.

Goodall, L. (1994). Market behavior of gaming stocks: An analysis of the first twenty years. Journal of Gambling Studies, 10, 323-337.

Granger, C.W.J. (1998). Some recent developments in a concept of causality. Journal of Ecoanometrics, 39, 199-211.

Greene, W. H. (2007). Econometric analysis, (6th Ed.). New Jersey, NY: Pearson. 
Hong, H., \& Kacperczyk, M. (2009). The price of sin: the effects of social norms on markets. Journal of Financial Economics, 93, 15-36.

Kim, I., \& Venkatachalam, M. (2006). Are sin stocks paying the price for their accounting sins? Working Paper.

King, R. G., Plosser, C. I., Stock, J. H., \& Watson, M.W. (1991). Stochastic Trends and Economic Fluctuations. American Economic Reivew, 81, 819-840.

Kwiatkowski, D., Phillips, P.B., Schmidt, P., \& Yongcheol, S. (1992). Testing the null hypothesis of stationarity against the alternative of a unit root. Journal of Econometrics, 54, 159-178.

Little, K. (2010). Rising unemployment hurts stocks, About.com: Stocks, February 10.

Moscarini, G., \& Postel-Vinay, F. (2010). Unemployment and Small Cap Returns. American Economic Review (papers and proceedings), 100, 333-337.

Marcet, A. (2005). Overdifferencing VAR's is O.K. Working Paper.

Newbold, P., \& Bos, T. (1990). Introductory Business Forecasting. Dallas, TX: South-Western Publishing Co.

Ng, S., \& Perron, P. (2001). Lag Length Selection and the Construction of Unit Root Tests with Good Size and Power. Econometrica, 69, 1519-1554.

Sharpe, W. (1964). Capital Asset Prices: A theory of market equilibrium under conditions of risk. Journal of Finance, 19, 425-442.

Watson, M.W. (1994). Vector autoregressions and cointegration. Handbook of Econometrics (eds. Engle, R.F. and McFadden, D.L.), IV, Elsevier Science B.V.

Wojdylo, J. (2009). Best prediction of the stock market and economy-unemployment rate, Subprime Blogger, March 17.

Waxler, C. (2004). Stocking up on sin: How to crush the market with vice- based investing. Hoboken, N.J.: John Wiley and Sons. 


\section{Appendix A-I}

Trend in US Casino Gaming Revenue and Forecast for 2011-2015

\begin{tabular}{|c|c|c|c|c|c|c|c|c|c|c|}
\hline$\frac{1}{1} \frac{1}{3}$ & & $\stackrel{\llcorner}{+}$ & & $\begin{array}{l}\varphi \\
\stackrel{+}{i}\end{array}$ & & $\stackrel{\gamma}{\dot{\sigma}}$ & & $\stackrel{?}{\sim}$ & & 웅. \\
\hline 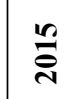 & 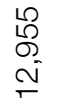 & $\stackrel{\nabla}{\circ}$ & $\begin{array}{l}\frac{10}{0} \\
\infty \\
\sim \\
\sim\end{array}$ & $\frac{\text { Oִ }}{\Gamma}$ & $\begin{array}{l}\text { 足 } \\
\text { m. } \\
\text { m. }\end{array}$ & $\stackrel{\circ}{\circ}$ & $\begin{array}{l}8 \\
\stackrel{+}{*} \\
\dot{v}\end{array}$ & $\stackrel{\circ}{\circ}$ & $\begin{array}{l}\text { N } \\
\stackrel{N}{0} \\
\aleph^{2}\end{array}$ & $\bar{\theta}$ \\
\hline$\stackrel{ \pm}{\bar{\sim}}$ & $\begin{array}{l}\text { O } \\
\underset{N}{N} \\
\end{array}$ & $\begin{array}{l}0 \\
0\end{array}$ & $\begin{array}{l}\text { P } \\
\infty \\
\text { N }\end{array}$ & $\stackrel{L}{\underset{1}{\sim}}$ & $\begin{array}{l}\stackrel{\rho}{\circ} \\
\stackrel{-}{\infty} \\
\stackrel{-}{m}\end{array}$ & $\sigma^{\circ}$ & $\begin{array}{l}\stackrel{8}{ } \\
\underset{\sim}{N}\end{array}$ & $\stackrel{N}{N}$ & $\begin{array}{l}\circ \\
\frac{0}{E} \\
\\
0\end{array}$ & مُ \\
\hline 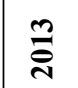 & 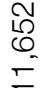 & $\stackrel{\varphi}{\dot{\sim}}$ & 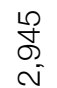 & $\stackrel{P_{+}}{+}$ & $\begin{array}{l}8 \\
\stackrel{i}{N} \\
0\end{array}$ & 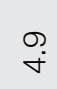 & $\begin{array}{l}8 \\
? \\
0\end{array}$ & $\stackrel{\infty}{\sim}$ & \begin{tabular}{l}
$\hat{9}$ \\
\multirow{9}{0}{} \\
0
\end{tabular} & $\tau^{\circ}$ \\
\hline సี & 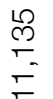 & $\underset{\sim}{\check{\sigma}}$ & 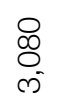 & 产 & $\begin{array}{l}8 \\
\infty \\
\infty \\
\infty 0^{-}\end{array}$ & $\stackrel{\gamma}{\dot{\sigma}}$ & $\begin{array}{l}8 \\
\text { o } \\
\text { o }\end{array}$ & $\stackrel{N}{N}$ & $\begin{array}{l}\frac{0}{0} \\
\text { s. } \\
0\end{array}$ & $\stackrel{\sim}{\sim}$ \\
\hline$\overline{\bar{\sim}}$ & $\begin{array}{l}8 \\
\stackrel{1}{0} \\
0\end{array}$ & $\stackrel{\infty}{\stackrel{\infty}{\sim}}$ & $\begin{array}{l}8 \\
\text { m } \\
m\end{array}$ & $\stackrel{+}{\stackrel{*}{*}}$ & $\begin{array}{l}8 \\
\stackrel{0}{1} \\
\end{array}$ & $\begin{array}{l}\infty \\
\dot{c}\end{array}$ & $\begin{array}{l}8 \\
8 \\
\infty\end{array}$ & $\stackrel{\infty}{\infty}$ & $\begin{array}{l}8 \\
0 \\
0 \\
0\end{array}$ & $\stackrel{\llcorner}{\infty}$ \\
\hline$\stackrel{\text { సิ }}{\text { N }}$ & 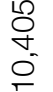 & ¿ & $\begin{array}{l}\llcorner 0 \\
\mathbb{0} \\
1 \\
m\end{array}$ & $\begin{array}{l}0 \\
0 \\
1\end{array}$ & $\begin{array}{l}2 \\
0 \\
0 \\
0 \\
0\end{array}$ & $\sigma_{0}^{\circ}$ & & $\begin{array}{l}\infty \\
\stackrel{\sim}{N}\end{array}$ & \begin{tabular}{l}
$\infty$ \\
$\infty$ \\
$\infty$ \\
\multirow{j}{*}{} \\
$N-$
\end{tabular} & $\stackrel{N}{0}$ \\
\hline ڤ్సે & $\begin{array}{l}\text { @్ } \\
\text { Oె } \\
0\end{array}$ & $\begin{array}{l}\stackrel{+}{0} \\
\stackrel{+}{+}\end{array}$ & $\begin{array}{l}\text { Ș } \\
\text { O্ }\end{array}$ & $\begin{array}{l}\stackrel{N}{\infty} \\
\stackrel{\Gamma}{1}\end{array}$ & 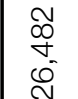 & $\frac{0}{T}$ & 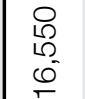 & $\stackrel{\circ}{\circ}$ & $\begin{array}{l}\infty \\
0 \\
0 \\
0 \\
10\end{array}$ & $\stackrel{\stackrel{\rho}{P}}{\stackrel{P}{p}}$ \\
\hline 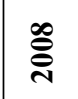 & $\begin{array}{l}\text { o) } \\
\text { م) } \\
=\end{array}$ & $\begin{array}{l}\stackrel{0}{0} \\
\stackrel{0}{+} \\
\Gamma_{1}\end{array}$ & 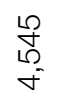 & $\stackrel{\stackrel{0}{i}}{i}$ & 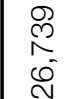 & $\stackrel{m}{\sim}$ & 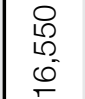 & $\stackrel{\Upsilon}{\Gamma}$ & 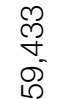 & $\stackrel{\uparrow}{\tau}$ \\
\hline 今్ & $\begin{array}{l}\hat{\sigma} \\
\bar{\rho} \\
\sigma\end{array}$ & $\stackrel{\infty}{\Gamma}$ & 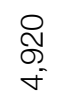 & 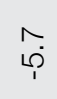 & 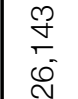 & 웅 & $\begin{array}{l}8 \\
0 \\
0 \\
0 \\
0\end{array}$ & $\underset{\sim}{\stackrel{N}{\sim}}$ & $\begin{array}{l}\stackrel{9}{8} \\
\text { 8 } \\
8\end{array}$ & $\stackrel{\sim}{\sim}$ \\
\hline ఫ్స & 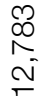 & $\stackrel{\nabla}{\infty}$ & 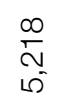 & $\stackrel{\circ}{\forall}$ & $\begin{array}{l}\mathbb{D} \\
\infty \\
\infty \\
\mathbb{0}\end{array}$ & $\begin{array}{l}\stackrel{0}{\circ} \\
\stackrel{\circ}{\circ}\end{array}$ & 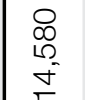 & $\stackrel{\nabla}{0}$ & $\begin{array}{l}\stackrel{P}{f} \\
\stackrel{f}{f}\end{array}$ & $\stackrel{\nabla}{\infty}$ \\
\hline ڤే & $\begin{array}{l}\frac{\pi}{0} \\
\frac{\pi}{00} \\
\frac{\pi}{2}\end{array}$ & 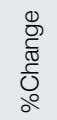 & 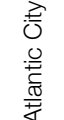 & 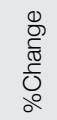 & 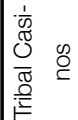 & 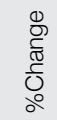 & 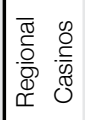 & $\begin{array}{l}0 \\
\stackrel{0}{0} \\
\frac{0}{0} \\
0 \\
0 \\
0\end{array}$ & $\begin{array}{l}\overline{\widetilde{\sigma}} \\
\stackrel{0}{0}\end{array}$ & 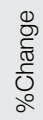 \\
\hline
\end{tabular}




\section{Appendix A-II}

Trend in global Casino Gaming Revenue and Forecast for 2011-2015

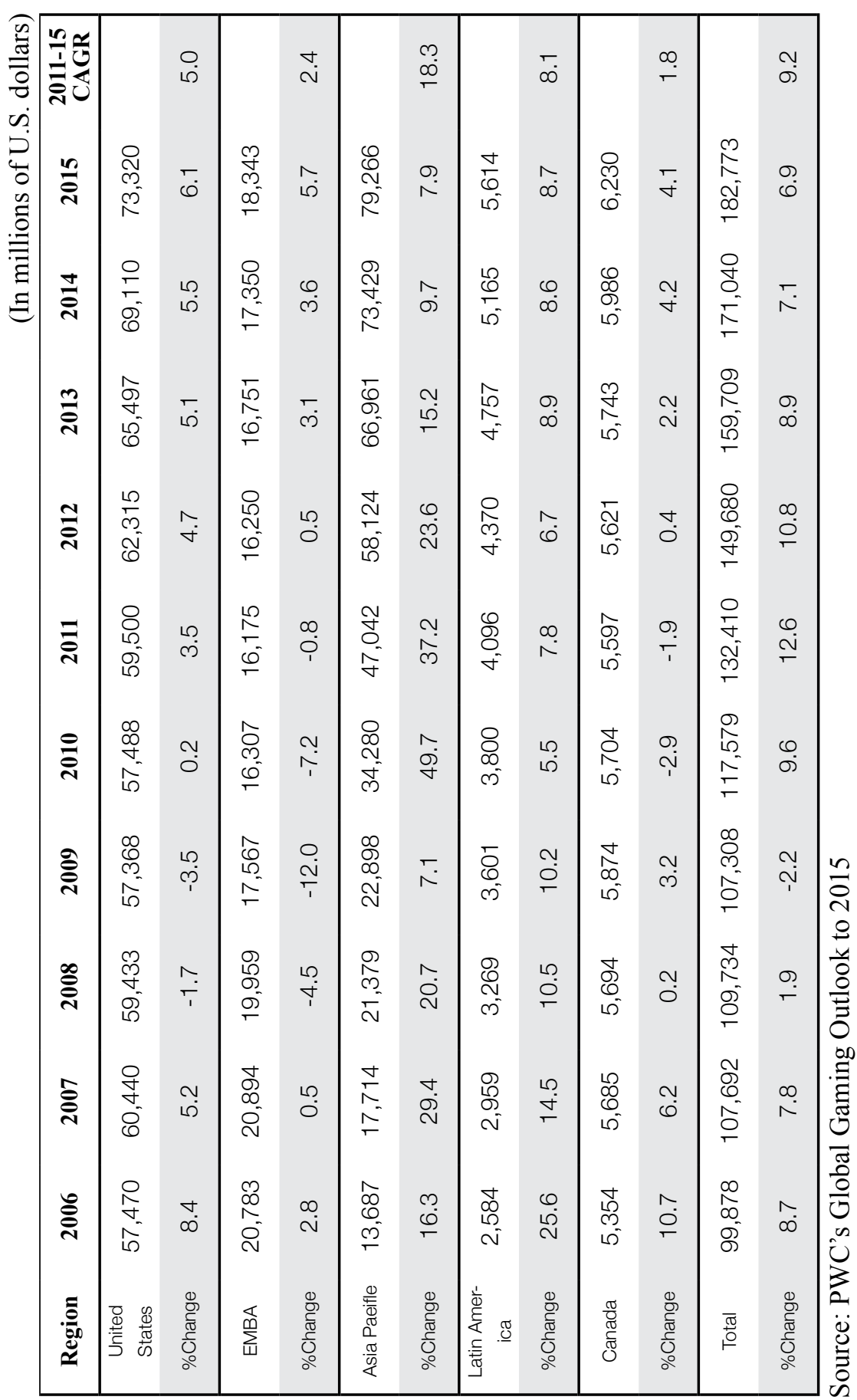


Appendix - C

Impulse Response Analyses

(Cholesky one S.D. Innovations \pm 2 S.E.)
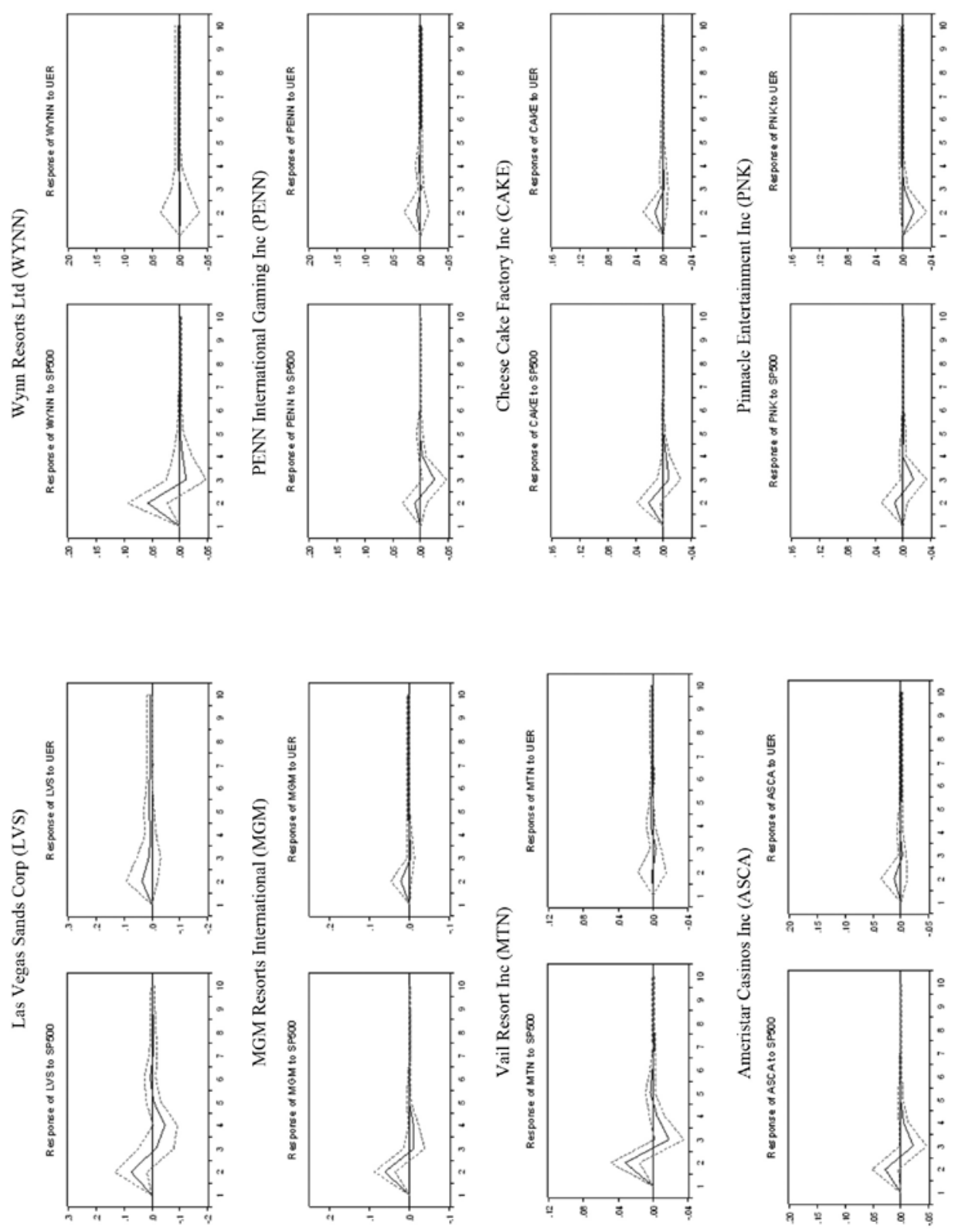


\section{Appendix - D*}

(Variance Decomposition)

\begin{tabular}{|c|c|c|c|c|c|c|c|c|c|c|c|c|c|c|c|c|c|}
\hline$\frac{5}{a}$ & $\begin{array}{l}\text { N } \\
\infty \\
\text { o } \\
\infty \\
\infty \\
\infty \\
\infty\end{array}$ & $\begin{array}{l}\bar{\sigma} \\
\overline{8} \\
\varnothing \\
\infty\end{array}$ & $\begin{array}{l}8 \\
\mathbb{1} \\
1 \\
0 \\
0 \\
0 \\
0\end{array}$ & 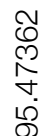 & \begin{tabular}{l}
\multirow{J}{J}{} \\
\multirow{J}{*}{} \\
$\infty$ \\
$\dot{J}$
\end{tabular} & 氙 & 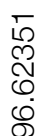 & 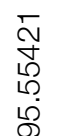 & 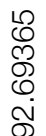 & $\begin{array}{l}\widetilde{N} \\
\stackrel{N}{N} \\
\stackrel{N}{N} \\
\bar{\sigma}\end{array}$ & $\begin{array}{l}0 \\
\frac{0}{N} \\
\stackrel{0}{0} \\
\stackrel{0}{8}\end{array}$ & & & & & & \\
\hline $\begin{array}{l}\stackrel{8}{\circ} \\
\frac{n}{\sim} \\
\frac{n}{2}\end{array}$ & 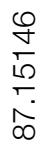 & 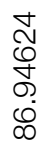 & 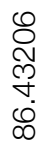 & 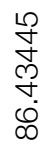 & 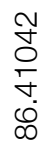 & 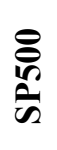 & \begin{tabular}{l} 
D \\
$\infty$ \\
0 \\
\multirow{0}{*}{} \\
\end{tabular} & $\begin{array}{l}ம \\
\widetilde{6} \\
\varnothing \\
0 \\
0 \\
1\end{array}$ & $\begin{array}{l}\stackrel{N}{\infty} \\
\text { m } \\
\stackrel{N}{N} \\
\stackrel{n}{N}\end{array}$ & $\begin{array}{l}\infty \\
\frac{1}{\rho} \\
\infty \\
\frac{1}{N} \\
i\end{array}$ & 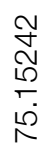 & & & & & & \\
\hline 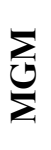 & $\begin{array}{l}8 \\
8 \\
8 \\
8 \\
8 \\
8\end{array}$ & 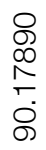 & $\begin{array}{l}0 \\
\stackrel{2}{0} \\
\infty \\
0 \\
0 \\
\dot{8}\end{array}$ & 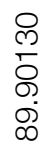 & $\begin{array}{l}\hat{0} \\
\infty \\
\infty \\
\infty \\
\infty \\
\infty \\
\infty\end{array}$ & $\frac{0}{U}$ & $\begin{array}{l}8 \\
8 \\
8 \\
8 \\
8 \\
\end{array}$ & 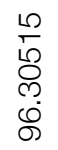 & $\begin{array}{l}\infty \\
0 \\
\infty \\
\\
\circ \\
\mathscr{0}\end{array}$ & 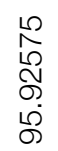 & 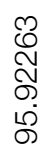 & & & & & & \\
\hline$\frac{1}{a}$ & 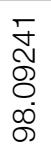 & 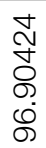 & 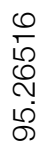 & 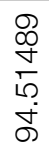 & 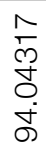 & $\frac{5}{\frac{1}{\sigma}}$ & $\begin{array}{l}\overline{1} \\
\sim \\
\infty \\
0 \\
\infty \\
\infty\end{array}$ & $\begin{array}{l}\infty \\
\text { D } \\
\infty \\
\infty \\
\infty \\
\end{array}$ & 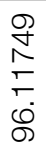 & $\begin{array}{l}\frac{1}{\square} \\
\frac{1}{0} \\
\emptyset \\
\dot{\sigma}\end{array}$ & 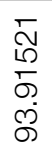 & $\frac{\vec{\alpha}}{\frac{1}{b}}$ & $\begin{array}{l}\text { @ } \\
0 \\
\infty \\
\infty \\
\infty \\
\infty \\
\infty \\
\infty\end{array}$ & 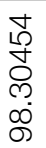 & $\begin{array}{l}\simeq \\
N \\
10 \\
0 \\
\mathscr{0} \\
\mathscr{0}\end{array}$ & $\begin{array}{l}m \\
\stackrel{N}{N} \\
\stackrel{N}{N} \\
\stackrel{\rho}{\infty}\end{array}$ & $\begin{array}{l}1 \\
\overline{8} \\
8 \\
0 \\
\text { வீ }\end{array}$ \\
\hline $\begin{array}{l}\stackrel{8}{\circ} \\
\stackrel{\circ}{n} \\
\end{array}$ & $\begin{array}{l}\infty \\
\infty \\
\overline{6} \\
\\
0 \\
0\end{array}$ & 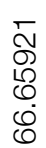 & 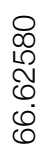 & $\begin{array}{l}1 \\
\text { లి } \\
\infty \\
0 \\
0 \\
0 \\
0\end{array}$ & 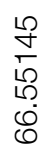 & 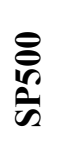 & $\begin{array}{l}\text { ○ } \\
\stackrel{1}{\circ} \\
\infty \\
\stackrel{0}{0} \\
\infty\end{array}$ & $\begin{array}{l}\stackrel{\sim}{N} \\
\stackrel{N}{\infty} \\
\infty \\
\infty \\
\infty \\
\sim\end{array}$ & 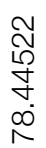 & 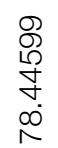 & 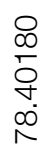 & $\frac{8}{8}$ & $\begin{array}{l}0 \\
0 \\
0 \\
0 \\
0 \\
8 \\
8\end{array}$ & 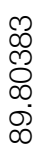 & 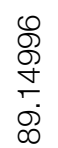 & $\begin{array}{l}\infty \\
8 \\
8 \\
\circ \\
\circ \\
\infty \\
\infty\end{array}$ & \begin{tabular}{l}
0 \\
\multirow{0}{0}{} \\
0 \\
0 \\
0 \\
$\infty$ \\
$\infty$
\end{tabular} \\
\hline$\frac{Z}{Z}$ & $\begin{array}{l}8 \\
8 \\
8 \\
8 \\
8 \\
\text { 으 }\end{array}$ & $\begin{array}{l}\text { న } \\
\varnothing \\
8 \\
\infty \\
\infty \\
\infty\end{array}$ & $\begin{array}{l}\infty \\
\stackrel{\infty}{N} \\
\stackrel{N}{\sim} \\
\stackrel{\infty}{\infty} \\
\infty\end{array}$ & 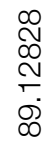 & $\begin{array}{l}\text { ठ } \\
\text { సু } \\
\text { ○̣ } \\
\text { வ }\end{array}$ & Z & \begin{tabular}{l}
8 \\
8 \\
8 \\
8 \\
8 \\
\hdashline
\end{tabular} & 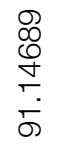 & $\begin{array}{l}\text { ले } \\
\varnothing \\
\varnothing \\
\varnothing \\
\infty \\
\infty\end{array}$ & 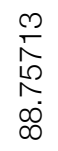 & \begin{tabular}{l}
$\mathcal{N}$ \\
Oे \\
\multirow{N}{*}{} \\
0 \\
$\infty$ \\
$\infty$ \\
$\infty$
\end{tabular} & $\frac{1}{Z}$ & $\begin{array}{l}8 \\
8 \\
8 \\
8 \\
8\end{array}$ & 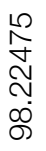 & $\begin{array}{l}\frac{\infty}{\infty} \\
\frac{\infty}{N} \\
\\
\text { の. }\end{array}$ & 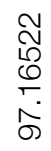 & 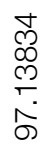 \\
\hline$\frac{6}{a}$ & $\begin{array}{l}\bar{\infty} \\
\text { N } \\
\text { Oे } \\
\text { ஸ் }\end{array}$ & $\begin{array}{l}\text { లి } \\
\text { గి } \\
0 \\
0 \\
\bar{\sigma}\end{array}$ & \begin{tabular}{l}
$\infty$ \\
\multirow{Z}{\forall}{} \\
$\infty$ \\
$\infty$ \\
$\infty$ \\
$\infty$
\end{tabular} & 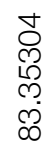 & 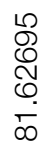 & 蒙 & 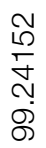 & 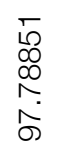 & 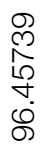 & $\begin{array}{l}\hat{n} \\
\text { J } \\
\text { m } \\
\dot{\rho}\end{array}$ & $\begin{array}{l}\bar{\sim} \\
\stackrel{0}{ } \\
\infty \\
\infty \\
\dot{\sigma}\end{array}$ & $\frac{\underline{a}}{b}$ & $\begin{array}{l}0 \\
\stackrel{N}{0} \\
\stackrel{N}{N} \\
\stackrel{n}{\sigma}\end{array}$ & 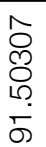 & 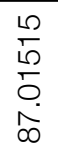 & $\begin{array}{l}\hat{D} \\
\infty \\
0 \\
0 \\
\dot{0} \\
\infty\end{array}$ & 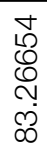 \\
\hline 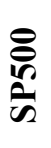 & 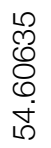 & 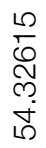 & 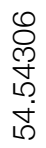 & 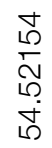 & 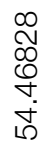 & $\begin{array}{l}8 \\
\text { ம } \\
\text { คิ }\end{array}$ & 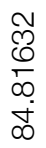 & $\begin{array}{l}\infty \\
\infty \\
\infty \\
\infty \\
\infty \\
\infty \\
\infty\end{array}$ & 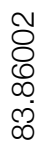 & $\begin{array}{l}\text { P } \\
\text { ป } \\
\infty \\
\infty \\
\infty \\
\infty\end{array}$ & $\begin{array}{l}8 \\
\mathbb{0} \\
\varnothing \\
\varnothing \\
\infty \\
\infty \\
\infty\end{array}$ & $\frac{8}{8}$ & 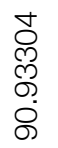 & $\begin{array}{l}\infty \\
\sim \\
\text { N } \\
\infty \\
\infty \\
\infty \\
\infty\end{array}$ & $\begin{array}{l}\text { ஜ } \\
\infty \\
\infty \\
0 \\
0 \\
\infty \\
\infty\end{array}$ & $\begin{array}{l}\text { J } \\
\hat{0} \\
0 \\
0 \\
\infty \\
\infty\end{array}$ & $\begin{array}{l}\hat{N} \\
0 \\
0 \\
0 \\
\infty \\
\infty\end{array}$ \\
\hline$\frac{\infty}{a}$ & $\begin{array}{l}8 \\
8 \\
8 \\
8 \\
8\end{array}$ & 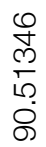 & 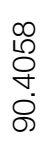 & $\begin{array}{l}8 \\
8 \\
8 \\
\varnothing \\
\infty \\
\infty\end{array}$ & $\begin{array}{l}\bar{\sigma} \\
\overline{0} \\
\infty \\
\infty \\
\infty\end{array}$ & $\underset{\mathrm{Z}}{\mathrm{Z}}$ & $\begin{array}{l}8 \\
8 \\
8 \\
8 \\
8 \\
\end{array}$ & 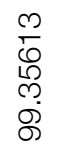 & $\begin{array}{l}\hat{N} \\
\hat{N} \\
\hat{N} \\
0 \\
0\end{array}$ & 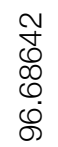 & $\begin{array}{l}8 \\
8 \\
0 \\
00 \\
0 \\
0\end{array}$ & $\underset{\Downarrow}{\mho}$ & $\begin{array}{l}8 \\
8 \\
8 \\
8 \\
8\end{array}$ & $\begin{array}{l}\infty \\
0 \\
N \\
\sim \\
\infty \\
0 \\
\mathscr{0}\end{array}$ & 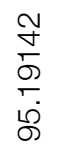 & $\begin{array}{l}N \\
\infty \\
\infty \\
\infty \\
\varnothing \\
\circ \\
\dot{\rho}\end{array}$ & 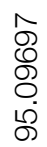 \\
\hline 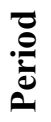 & $\tau$ & $\sim$ & $m$ & $\nabla$ & ما & & $\Gamma$ & $\sim$ & m & $\nabla$ & ما & & $\tau$ & $\sim$ & m & $\checkmark$ & ما \\
\hline
\end{tabular}




\section{APPENDIX - B*}

The Cheesecake Factory Inc (CAKE) is traded on NASDAQ and is headquartered in Calabasas Hills, California. Its primary businesses include restaurant and bakery operations. The Company has approximately 170 restaurants operating nationwide. The market capitalization was 2.01 billion dollars in 2012. Sales and income are growing at close to a $3 \%$ rate. The sales have been 1.81 billion dollars in the last year.

Pinnacle entertainment Inc. (PNK) is traded on the NYSE and headquartered in Las Vegas, Nevada. The company is an owner, operator and developer of casinos and related entertainment facilities. The company operates in several states as well as Asia. Their market capitalization was $\$ 852.37$ million in 2012 . Sales were 1.2 billion dollars in the last year. Income growth was negative for the period but the sales growth has been almost $5 \%$.

Ameristar Casinos Inc. (ASCA) is traded on NASDAQ and headquartered in Las Vegas. The company has 8 casinos in seven different markets in the US. In July of 2012 it purchased Creative Casinos of Louisiana in its entirety. The market capitalization for Ameristar was $\$ 864.51$ million in 2012. Sales have been 1.2 billion dollars in the last year. The growth rate in sales has been slightly negative but the income growth rate has been over $1,000 \%$

Vail Resort Inc. (MTN) is traded on the NYSE and headquartered in Colorado. Vail is a holding company consisting of operations in Mountain (ski Resorts), lodging and Real Estate. They acquired several new properties in 2012. Their Market capitalization was 2.22 billion dollars in 2012. Sales were $\$ 1.07$ billion in the last year. The growth rates in sales and income were negative for the last year.

Penn National Gaming Inc. (PENN) is traded on NASDAQ and is headquartered in Pennsylvania. Penn is the owner and manager of gaming properties and race tracks throughout the US and in Canada. The market capitalization for the company was $\$ 4.24$ billion in 2012 . Sales in the last year were $\$ 2.9$ billion. The growth rate in sales was almost $6 \%$, but the growth rate in income was negative. 
MGM Resorts International (MGM) is traded on NYSE and headquartered in Las Vegas. The company is engaged primarily in the gaming business with 15 resorts in the US and more in China under the name MGM Macau. The market capitalization of the firm was $\$ 6.29$ billion in 2012 . The Sales in the last year was $\$ 9.16$ billion. The growth rate in sales was $17 \%$, and the income growth rate was negative for the period.

Wynn Resorts Ltd (WYNN) is traded on NASDAQ and headquartered in Las Vegas. The company is a developer, and operator of casino properties. The company operates in Las Vegas and in Macau. The market capitalization of the company was $\$ 12.48$ billion last year. The last year's sales were $\$ 5.15$ billion. The growth in sales for the period was slightly negative and the growth in income was more negative $(18.2 \%)$.

Las Vegas Sands Corp (LVS) is traded on the NYSE and is headquartered in Las Vegas. The company is a developer of destination properties in the US and China. The market capitalization of the company was $\$ 45.95$ billion in 2012 . The last year's sales figures were $\$ 11.13$ billion. The sales growth and income growth rates for LVS were around $20 \%$.

\section{BIOGRAPHICAL SKETCH OF AUTHORS}

Dr. Matiur Rahman is a Professor of Finance and MBA Director at McNeese State University. He earned his Ph.D. in economics from Southern Methodist University, Dallas, Texas. He is a prolific researcher and published numerous theoretical and empirical articles in refereed U.S. and foreign journals in economics, finance and international business.

Dr. Muhammad Mustafa is a Professor of Economics at South Carolina State University. He teaches courses in economics, finance and agribusiness. He is an avid researcher and published empirical articles quite extensively in his fields of specialization in refereed journals in the USA and abroad.

Dr. Stephen Caples is a Professor of Finance at McNeese State University. He earned his Ph.D. in finance from the University of Texas at Arlington. He has published a host of empirical articles in refereed finance and economic journals in the USA. 